Relations industrielles

Industrial Relations

\title{
The Staff of CATALYST : Upward Mobility. New-York, Holt, Rinehart and Winston, 1982, 292 pp., ISBN 0-03-056163-9
}

\section{Alexander J. Matejko}

Volume 39, numéro 2, 1984

URI : https://id.erudit.org/iderudit/050041ar

DOI : https://doi.org/10.7202/050041ar

Aller au sommaire du numéro

Éditeur(s)

Département des relations industrielles de l'Université Laval

ISSN

0034-379X (imprimé)

1703-8138 (numérique)

Découvrir la revue

Citer ce compte rendu

Matejko, A. J. (1984). Compte rendu de [The Staff of CATALYST : Upward Mobility. New-York, Holt, Rinehart and Winston, 1982, 292 pp., ISBN 0-03-056163-9]. Relations industrielles / Industrial Relations, 39(2), 398-399.

https://doi.org/10.7202/050041ar

Tous droits réservés @ C Département des relations industrielles de l'Université Laval, 1984
Ce document est protégé par la loi sur le droit d'auteur. L’utilisation des services d'Érudit (y compris la reproduction) est assujettie à sa politique d'utilisation que vous pouvez consulter en ligne.

https://apropos.erudit.org/fr/usagers/politique-dutilisation/ 
provide adequate wage rates or conditions. When they succeed in securing effective representation of B.P.B.A. firms their main aim is to improve upon B.P.B.A. conditions and often to remove workers from the scope of the B.P.B.A. agreement, by implementing an alternative national agreement with higher base rates.

... More important, on the institutional side, is the attitude of the employers in the small-firm and box-making sector. The firms supported the establishment of an agreement between the B.P.B.A. and the trade unions to fill the gap created by the abolition of the Wages Council. The alternative was to leave themselves open to pressure to adopt other packaging agreements, or even the print agreement, as the basis for wage determination. However most of the B.P.B.A. firms have accepted the change to national, voluntary collective bargaining only because it has made little effective difference to their methods of wage determination.»

Thus the authors remark that although the decision to abolish the Council was a reasonable one in the circumstances, successful development of collective bargaining was dependent on a number of factors. In the event these factors have not borne the soughtfor fruit with the result that abolition has brought little of benefit to many workers in the Paper Box industry. As Craig et al conclude

... «there is little evidence that the abolition of the Paper Box Wages Council provided any benefits which could justify the removal of protection against low pay - protection still required by a minority of the industrys' labour force.»

The Report is useful indeed. A large amount of data has been generated by the survey and this is presented in a clear and readable form. The message is obvious. Once the decision to abolish statutory support through a Wages Council is made the likelihood of vigorous collective bargaining being established as a replacement is by no means a certainty. If collective bargaining fails to develop into this vacuum there is a strong possibility that the relative position of wages and conditions of a number of workers will deteriorate as in the Paper Box industry. It is to be hoped that this consequence is appreciated by politicians before decisions are made to expose more groups of British workers to the principles of Ricardian economics.

\section{David BRIGHT}

University of Durham, England

Upward Mobility by the staff of 'Catalyst', New York: Holt, Rinehart and Winston, 1982, pp. XXX +292,

ISBN 0-03-056163-9

This is a book for women how to overcome the career problem and go successfully ahead against all hindrances and discriminations: how to make an effective selfevaluation and given your Ego a money boost; how to make an adequate diagnosis of the work situation, hierarchies and power, workmates, etc.; where to find prospects for moving up; which skills are needed for getting ahead; how to make the personal balance of assets and liabilities; how to prepare for a better job on a shoestring budget; which is the real value of formal training; what high visibility can do for a candidate; how to make the right connections; how to recognize the lucky break and exploit it; how to get recognition together with an adequate salary, title and status; how to utilize in the office politics the rules of the game; how to make tokenism work for you.

This book is based on the assumption that women need to break out of traditionally female and overcrowded job fields and enter the less familiar, less obvious, but more promising, lucrative, and presently maledominated areas of business, science, and technology. 
There is an urgent need of courage, not to be afraid of success, gain confidence, boost the confidence level, and fight for promotion. «Power is one of the things that business is all about. If you think power is a dirty, masculine word, maybe you don't belong in the business world at all» (p. XXVII).

Some aggressiveness is badly needed in order women to be recognized. No illusions are allowed about colleagues being genuinely friendly, bosses judging subordinates according to their work and loyalty, people being promoted according to their real values. The sub-rosa communication network within a company has to be taken into consideration. "When your company is actually a highly political organization where who you know is as important as what you know, you're proceeding on the wrong theory, and that's why you may never get promoted») (p. 47).

Therefore, to map out an informal organizational chart is one of the important suggestions in the book. The employer is ready to apply various tricks: discriminate people according to their sex or age, make employees victims of technological displacement, fire people for a trumpe-up cause when the real reason for the dismissal is their high salary, rely on job-enrichment gimmicks to compensate for meager wages or raises, for the candidates to take a polygraph test as a condition of employment, try to pass off a job-rotation program as a managementtraining program, etc.

When taking an energetic action against discrimination it is necessary to take into consideration all involved circumstances and not to react emotionally appearing as a naive loser. Women have have to even more diligent about long-term planning than the average man, whose working life may proceed with very little interruption.

A good problem-solving skill is valuable but the business etiquette is also important, including even not sending out sloppylooking business letters or mistreating business associates' secretaries. It is necessary to know well the mechanics of salary negotiation in order to secure for oneself an adequate increment.

The salesmenship skill in playing for one's own advantage all personal assets is emphasized in the book as very important. Formal training is a big-ticket item with no builtin guarantees but it is important to take advantage of all other available confidence builders. A high visibility is a great asset and it is important to do as much as possible in order to appear as newsworthy. Networking among working women and finding the powerful mentors, «these two types of support systems create a skyrocket effect and cannot fail to advance a woman faster than her less fortunate colleagues» (p. 203).

In order to be lucky in the professional career, it is necessary to extrovert, have a magnetic personality, be aware of one's own feelings, know a difference between a hunch and a hope, do adequately the homework, recognize an opportunity when it comes along, be prepared to take risks, be a skeptic, know when to quit, be able to admit one's own mistakes. «Prudence and Persistence are the better part of Success (...). Hard work is impressive if it is highly visible. Image is important-sometimes, anyway-and having your head in the right place helps a lot. But the real key is action» (pp. 272-273).

This book is very characteristic for the growing individual and collective struggle of working women for a genuine equality and promotion. The strategy of success seems to be simulated after the traditional male thinking and practice, as well as fitting the competitive market. Is any chance in this sensitive field for upgraded women to bring something really new in the career orientation, human relations approach, humanisation of work, etc.? This aspect is entirely missing in this other way valuable book.

Alexander J. MATEJKO University of Alberta 